\title{
FIRST CONFIRMED RECORD OF A LESSER GOLDFINCH
IN SASKATCHEWAN
}

Robert Holtkamp

792 Broadway Street West

Yorkton, SK S3N 2X5

rholtkamp@msn.com

It was a beautiful spring day on 30 April 2020 - warm and not too windy. While taking a coffee break from spring clean-up in my Yorkton yard, I noticed a couple of Purple Finches (Haemorhous purpureus), a few House Sparrows (Passer domesticus) and a Downy Woodpecker (Dryobates pubescens) busy at my bird feeders. Suddenly, I saw a bright flash of colour. It was a bird I had never seen before. It was bright yellow below with mostly black upper parts and white wing markings, like an oddly coloured goldfinch. I grabbed my camera and snapped a dozen or so shots (Figure 1) until the bird disappeared.

Using the iBird application on my cell phone, I typed in American Goldfinch. I then tapped 'similar' and voila! It was the bird I saw in my yard - a beautiful, male Lesser Goldfinch (Spinus psaltria).

Minutes later, the Lesser Goldfinch returned and I took many more pictures (Figure 2). The bird was not easily intimidated by more aggressive birds, and at one point perched next to a House Sparrow at the feeder. The Lesser Goldfinch ate and drank his fill and flew about in the trees (Figure 3), spending approximately 40 minutes in my yard before carrying on with his journey. After that visit, I continued to watch my feeders, trees, shrubs and flower beds, but the bird never returned. Incidentally, I saw

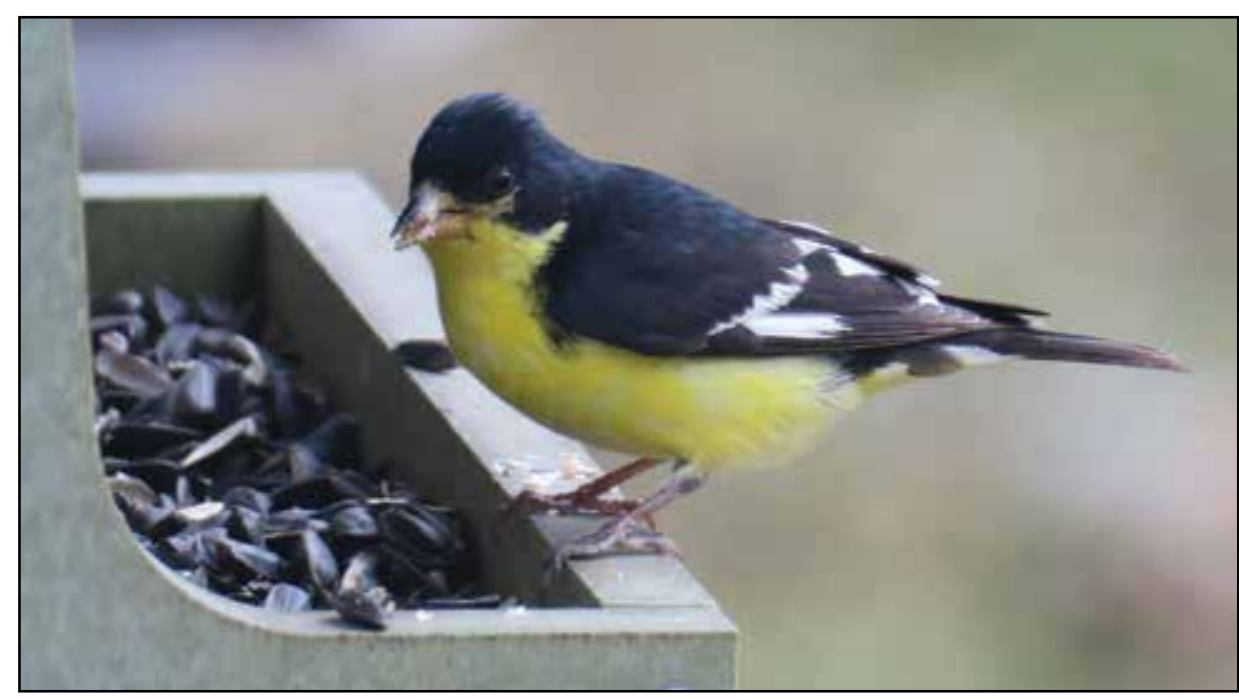

FIGURE 1: The bird showed bright yellow below with mostly black upper parts and white wing markings. Photo credit: Robert Holtkamp.

my first American Goldfinch (Spinus tristis) of the season on 12 May.

\section{Identification}

The Lesser Goldfinch is a small, social songbird that is found throughout the southwestern United States. At 4.5 inches in length, the Lesser Goldfinch is the smallest finch in North America and one of the smallest true finches (family Fringillidae) in the world. ${ }^{1}$ Its natural habitat is open woodlands and riparian areas, but it also occurs in weedy patches of agricultural areas and at bird feeders in suburbs with ornamental trees and shrubs. ${ }^{2}$ Males are distinctive with their entirely black crowns; however, adult females and immature birds resemble the American Goldfinch. Although the Lesser Goldfinch tends to be more greenish, the best distinguishing feature is the white patch at the base of the primaries, which is best seen in flight. ${ }^{3}$

\section{Range}

The Lesser Goldfinch is a resident from Washington, Oregon and northern Nevada east to northern Colorado and Texas, and south beyond the Mexico/U.S. border. Black-backed and green-backed males were previously treated as different subspecies, but are now thought to be colour morphs. ${ }^{4}$ The black-backed form predominates east of longitude $106^{\circ} \mathrm{W}$, while the greenbacked form occurs mainly farther west. ${ }^{4}$ Preferred habitats include oak savannahs and woodlands. ${ }^{5}$ The photographs (Figures 1-3) show clearly that the Yorkton bird was a black-backed male.

Range limits can be quite dynamic and it is evident that the Lesser Goldfinch is extending its range northward, now breeding - at least rarely — from the extreme southern portion of British Columbia to western Nebraska and southwestern South Dakota. ${ }^{6,7,8}$ Beyond the 


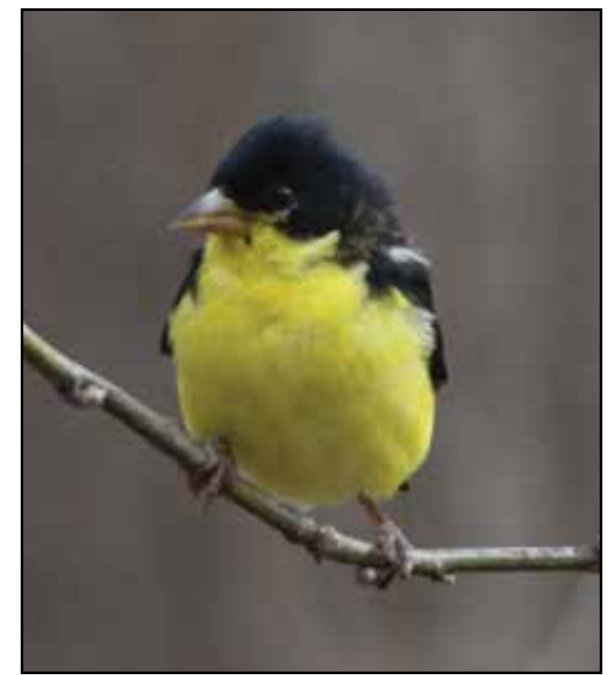

FIGURE 2: Several images of the Lesser Goldfinch were obtained on 30 April 2020. Photo credit: Robert Holtkamp.

breeding range, vagrants have been found across the United States to the Atlantic coast. There are scattered records from Maine to Florida documented on eBird, while records in Montana extend to within $60 \mathrm{~km}$ of Saskatchewan.

\section{Previous hypothetical records in Saskatchewan}

There have been two previous reports of a Lesser Goldfinch in Saskatchewan, although both are hypothetical as they lack a specimen, photo or song recording. The first was a bird with "bright green" upper parts, as well as two others with a greenish tinge that were part of a goldfinch flock that John Douglas saw feeding on roadside wild sunflower seeds near Maple Creek in mid-August 1997. ${ }^{9}$ A more credible sighting was of a male of the blackbacked form seen briefly at a feeder in Weyburn on 14 August 2011 by Carol Bjorklund. ${ }^{3}$

\section{Records elsewhere in Canada}

R. Toochin compiled details for 13 accepted and two hypothetical records of Lesser Goldfinch in southern British Columbia from 1931 to 2013 , with the majority appearing since 2000. The first Canadian record of a Lesser Goldfinch was of

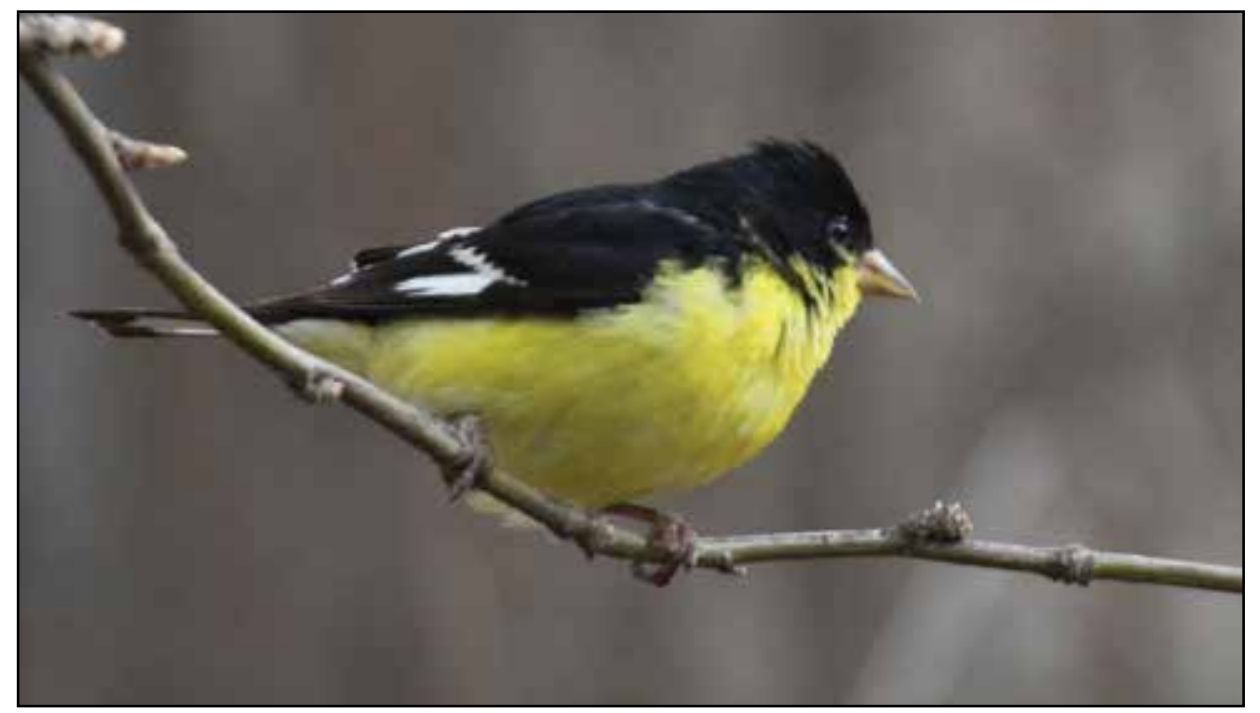

FIGURE 3: The Lesser Goldfinch ate and drank his fill, and flew about in the trees, for approximately 40 minutes before leaving. Photo credit: Robert Holtkamp.

a bird collected by T.T. McCabe in British Columbia on 9 June 1931. ${ }^{10}$ Since 2013, eBird data shows a rapidly increasing number of Lesser Goldfinch observations in the province and breeding was confirmed at Osoyoos in 2019. ${ }^{6}$

In Alberta, a Lesser Goldfinch was photographed at Cochrane on 15 May 2016. ${ }^{11}$ There have also been two records in Alberta reported with photographs on eBird. One bird was observed in Nacmine from 23 to 27 April 2014, and another bird was reported in Mountain View from 13 to 14 May 2018. The only record east of Saskatchewan is of a bird observed in Toronto on 10 August 1982. ${ }^{12}$ This new, confirmed record for Saskatchewan therefore significantly extends the range of known vagrancy for the Lesser Goldfinch. This appears to be only the second black-backed male to be reported in Canada, the first being the Weyburn bird.

1. Wikipedia (2020) Lesser goldfinch. https://en.wikipedia.org/wiki/Lesser_goldfinch.

2. Watt D.J. and Willoughby E.J. (1999) Lesser Goldfinch (Carduelis psaltria). In The Birds of North America, No. 392 (Poole A. and Gill F., eds).

3. Smith AR, Houston CS, Roy JF, editors (2019) Birds of Saskatchewan. Nature Saskatchewan, Regina.
4. Willoughby EJ (2007) Geographic variation in color, measurements, and molt of the Lesser Goldfinch in North America does not support subspecific designation. The Condor 109:419436.

5. iBird Pro Guide to Birds. Field Guide to North America. Mitch Waite Group. iPhone Application.

6. British Columbia Rare Bird Alert (2019) Two new breeding records for BC! Blog post, http:// bcbirdalert.blogspot.com/2019/07/two-newbreeding-species-for-bc.html

7. Silcock WR, Jorgensen JG (2020) Lesser Goldfinch (Spinus psaltria), Version 1.0. In Birds of Nebraska — Online. https://birds. outdoornebraska.gov/lesser-goldfinch/.

8. Sohl TL (undated) Lesser Goldfinch Spinus psaltria. In South Dakota birds, birding, and nature. https://www.sdakotabirds.com/species/ lesser_goldfinch_info.htm

9. Douglas J. (1998) Possible sighting of lesser goldfinch. Blue Jay 56(4):240.

10. Toochin R (undated, ca. 2013) Status and occurrence of the Lesser Goldfinch (Spinus psaltria) in British Columbia. University of British Columbia online resource: https://ibis. geog.ubc.ca/biodiversity/efauna/documents/ LesserGoldfinch-RT-r.pdf

11. Lefebvre B (2016) Rare backyard bird: Lesser Goldfinch. Blog post, https:// birdscalgary.com/rare-backyard-bird-lessergoldfinch/

12. Fraser DM (1984) Lesser Goldfinch (Carduelis psaltria) at Toronto: Ontario's first record. Ontario Birds 2:120-123. 